\title{
Morphometric relationships and size at sexual maturity of the deep-sea Caribbean lobster Metanephrops binghami (Decapoda: Nephropidae) in the Colombian Caribbean
}

\author{
José Cusba ${ }^{1}$, Jorge Paramo, ${ }^{1, *}$
}

Edited by

Juan Carlos Salcedo-Reyes

(salcedo.juan@javeriana.edu.co)

1. Universidad del Magdalena, Grupo de Investigación

Ciencia y Tecnología Pesquera

Tropical (CITEPT).

Carrera 32 No. 22-08 Avenida del

Ferrocarril, Santa Marta.

*jparamo@unimagdalena.edu.co

Received: 29-11-2016

Accepted: 20-05-2017

Published on line: 10-08-2017

Citation: Cusba J, Páramo J. Morphometric relationships and size at sexual maturity of the deep-sea Caribbean lobster Metanephrops binghami (Decapoda: Nephropidae) in the Colombian Caribbean, Universitas Scientiarum, 22(2): 145 - 160, 2017. doi: 10.11144/Javeriana.SC22-2.mras

Funding: This work was financed by COLCIENCIAS (grant number 117-452-21288), Universidad del Magdalena, Universidad del Magdalena/Gobernación del Magdalena (Agreement No. 089) and the Instituto Colombiano de Desarrollo Rural (INCODER) - Subgerencia de Pesca y Acuicultura.

Electronic supplementary material: $\mathrm{N} / \mathrm{A}$

OPEN ACCESS

\begin{abstract}
This paper describes the morphometric relationships and size at sexual maturity of deep-sea Caribbean lobster. Data were obtained in the Colombian Caribbean in four trawling surveys in November and December 2009 between 200 and $550 \mathrm{~m}$ depth. 709 individuals with sizes between 53.65 and $191.00 \mathrm{~mm}$ (TL) (mean $121.17 \pm 27.13 \mathrm{~mm}$ ) were measured. $M$. binghami had a positive allometric growth. Lobsters of the family Nephropidae have a worldwide distribution and economic importance. High levels of biomass of Metanephrops binghami have been reported in the Colombian Caribbean and this species could become a potential new resource for the Western Atlantic fishery. However, prior to the development of a new fishery, more biological research is needed to understand the life cycle of this species. Aspects such as growth, spawning, recruitment, mortality, nursery areas and associated biodiversity should be carefully studied.
\end{abstract}

Keywords: Metanephrops binghami; morphometric relationships; Caribbean; Colombia; Deep-sea Caribbean lobster.

\section{Introduction}

Lobsters of the family Nephropidae are of great commercial importance in many fisheries around the world (Cobb \& Wang 1985, Holthuis 1991), and can be found from shallow waters to 1,400 meters depth on sand and mud bottoms (Tavares 2002). Within this family is the genus Metanephrops distributed in the Indo-Pacific, Eastern Pacific and Western Atlantic (Holthuis 1991, Chan et al. 2009, Robey et al. 2013). Some species of this genus have been reported as being of great economic importance such as Metanephrops mozambicus (Macpherson 1990) caught by industrial fisheries in East Africa (Robey et al. 2013), Metanephrops japonicus (Tapparone-Canefri 1873) which presents a high value in local fisheries of Japan (Okamoto 2008) and Metanephrops binghami (Boone 1927) that has potential for exploitation in Venezuelan waters (Gómez et al. 2000, Gómez et al. 2005). 
On the continental slopes of north-west Australia, three deep-sea crustaceans of the genus Metanephrops are exploited commercially: M. boschmai (Holthuis 1964), M. andamanicus (Wood-Mason 1891) and M. australiensis (Bruce 1966; Ward and Davis 1987; Wassenberg and Hill 1989). In addition, in New Zealand a deep-sea lobster fishery has been developed targeting scampi (M. challengeri Balss 1914; Smith 1999).

The deep-sea Caribbean lobster (M. binghami) has a wide distribution from the Bahamas Islands to French Guiana, including the Gulf of Mexico and Caribbean Sea, inhabiting depths ranging between 200 and $700 \mathrm{~m}$ (Holthuis 1991, Tavares 2002). Research on deep water in the Colombian Caribbean has reported the potential of M. binghami for a fishery with high commercial value, but at present there is no fishery for this species and there is no information about its biology, population dynamics and life history (growth, reproduction, etc.) (Paramo \& Saint-Paul 2012). However, for the management of fisheries it is very important to know the size structure, body growth and size at sexual maturity of commercially important species (Hilborn \& Walters 1992), which influence the structure and function of marine ecosystems (Haedrich \& Barnes 1997, Shin et al. 2005). Therefore, the objective of this study is to provide biological information on size structure, size at sexual maturity and morphometric relationships of the deep-sea Caribbean lobster Metanephrops binghami in the Colombian Caribbean.

\section{Materials and methods}

Sampling was carried out in November and December 2009. Samples were taken by trawling (30 min haul duration) in depths ranging from 200 to $550 \mathrm{~m}$, with at least two hauls per $100 \mathrm{~m}$ depth stratum, in the Colombian Caribbean. We used a commercial FURUNO FCV 1150 echo-sounder with a transducer at a frequency of $28 \mathrm{kHz}$ to trawling locations, with a total of 87 stations sampled (Figure 1). Samples were collected by a commercial shrimp trawler using a trawl with a cod-end mesh of size $44.5 \mathrm{~mm}$ from knot to knot (Paramo \& Saint-Paul 2012).

In the laboratory, the Caribbean lobster ( $M$. binghami) specimens were measured using twelve morphometric measurements of the body to the nearest $0.01 \mathrm{~mm}$, total wet weight (W) to the nearest $0.01 \mathrm{~g}$, and sex was determined. The morphometric variables recorded were: (1) total length (TL), (2) antennal spine width (ASW), (3) hepatic spine width (HSW), (4) cephalothorax length (CL), (5) diagonal cephalothorax length (DCL), (6) first abdominal segment length (FSL), (7) first abdominal segment width (FSW), (8) first abdominal segment height (FSH), (9) second abdominal segment length (SSL), (10) sixth abdominal segment height (SISH), (11) tail length (TaL) and (12) head length (HL) (Tzeng et al. 2001, Tzeng \& Yeh 2002, Paramo \& Saint-Paul 2010).

Differences in sizes and weights between females and males were analyzed using the non-parametric Mann-Whitney $U$ test $(\alpha=0.05)$. The length frequency distributions for females and males allowed calculating the sex ratio by size class (each $10-\mathrm{mm}$ length interval). A chi-square test was performed to establish significant differences between the total number of females and males and by size class with a reference of $50 \%$ sex ratio. Additionally, a Generalized Additive Modelling (GAM; Hastie \& Tibshirani 1990) was used to analyse the relation between the sex ratio and size class. 


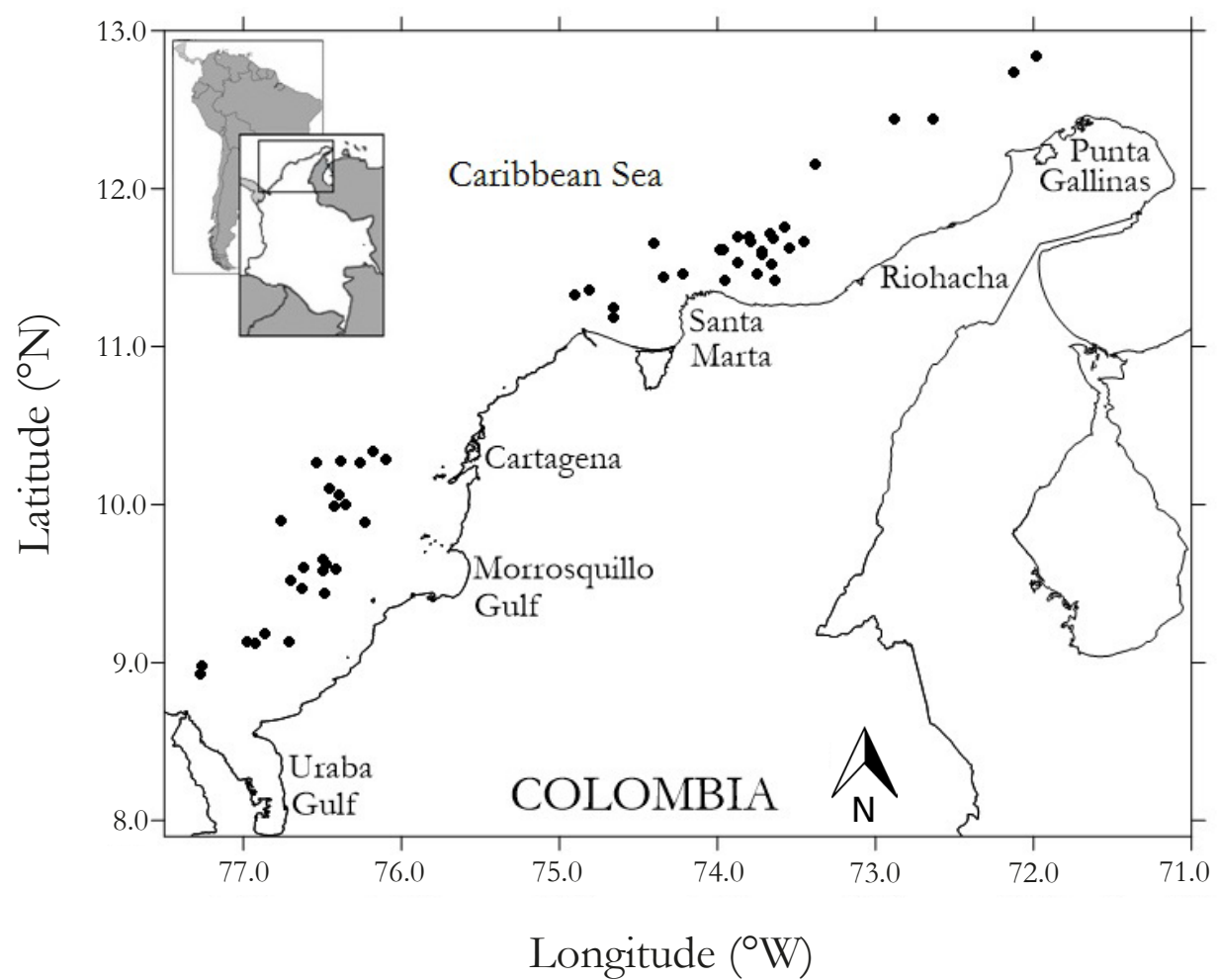

Fig. 1. Study area. Dots indicate the location of sampled stations during the survey in the Colombian Caribbean.

We used spline (s) smoothing with a Gaussian family to estimate the nonparametric functions. The probability level of the nonlinear contribution of the nonparametric terms was made with the significance value (P) for judging the goodness of fit (Burnham \& Anderson 2003).

The maturity of $M$. binghami was evaluated considering five macroscopic maturity stages for females. The ovary staging was based on the colour, according to Paramo \& Saint-Paul (2012): stage 1, white-immature; stage 2, opaque-in development; stage 3 , yellow-maturing; stage 4, green-mature; stage 5, ovigerous female carrying eggs on its pleopods (adapted from Mente et al. 2009). We considered stages I and II as immature and stages III, IV and V as mature. The proportion of mature individuals in each 10-mm length interval was recorded and modelled using a logistic function. To obtain an estimate for size at sexual maturity $\left(\mathrm{TL}_{50 \%}\right)$ we fitted the curve by leastsquares minimization using a nonlinear regression.

$$
\mathrm{P}(\mathrm{TL})=\frac{1}{1+\exp (\mathrm{a}+\mathrm{b} * \mathrm{TL})}
$$

Where $\mathrm{P}(\mathrm{TL})$ is the mature female proportion, $a$ and $b$ are the parameters estimated and $\mathrm{TL}$ is the total length. The size at $50 \%$ maturity is obtained by $\mathrm{TL}_{50 \%}=(-\mathrm{a} / \mathrm{b})(\mathrm{King} 2007)$. 
To analyse the onset of sexual morphological maturity in females and males, the total length and cephalothorax length were established as primary morphometric measurements, relating it to each of the different measures (Queirós et al. 2013). A regression model with segmented relation of the segment package was used (Muggeo 2003 , 2008). This model is based on the relations between two explanatory variables that are represented by two straight lines connected by a break point (Muggeo 2003, 2008). The fitting is based on the minimization of the gap parameter, which measures the space between the two regression lines on each side of the break point. When the algorithm converges, the "gap" parameter approaches to zero, minimizing the standard error of the break point (Muggeo 2008). The breaking points of the relationships between the two morphometric measurements were considered as indicative of the size at the beginning of maturity for females and males as long as the break points for which the value of $\mathrm{t}$ associated with the "gap" parameter were lower than two (Muggeo 2008). In addition, the Davies test was used to test significant differences between the slopes of the fitted segments (Davies 1987, Muggeo 2008, Queirós et al. 2013, Williner et al. 2014).

The length-weight relationship was modelled as a power law equation by regression of weight vs length $\boldsymbol{W}=\boldsymbol{a} \boldsymbol{L} \boldsymbol{t}^{\boldsymbol{b}}$ by logarithmic transformation $\ln \boldsymbol{W}=\ln \boldsymbol{a}+\boldsymbol{b} \ln$ $\boldsymbol{L} \boldsymbol{t}$ where $\boldsymbol{W}$ is the total weight in $\mathrm{g}, T L$ is the total length in $\mathrm{cm}, \boldsymbol{a}$ is the intercept and $\boldsymbol{b}$ is the allometry coefficient. As a measure of fit goodness, the determination coefficient $\left(\mathrm{R}^{2}\right)$ was used. The confidence interval of $95 \%$ for b was estimated and t-student test was conducted to determine if the lobster presented isometric growth $(\mathrm{H} 0: \mathrm{b}=3, \mathrm{a}=0.05)$. The morphometric relations were performed using least squares fitting to linear equation $\mathrm{Y}=\mathrm{a}+\mathrm{X}^{*} \mathrm{~b}$ where; $\mathrm{a}$ (intercept), $\mathrm{b}$ (slope), $\mathrm{Y}$ for TL and $\mathrm{X}$ for the independent variables (ASW, HSW, CL, DCL, FSL, FSW, FSH, SSL, SISH, $\mathrm{TaL}$ and HL). To evaluate differences in linear relationships between the sexes an analysis of covariance was performed (ANCOVA) (Zar 2009).

\section{Results}

The size of $M$. binghami females ranged between 53.65 and $178.00 \mathrm{~mm}$ TL (mean $118.94 \pm 24.73 \mathrm{~mm}$ ) and the size of males ranged between 60.17 and $191.00 \mathrm{~mm}$ TL (mean $123.93 \pm 29.52 \mathrm{~mm}$ ). The weight of females ranged between 1.70 and $79.70 \mathrm{~g}$ (mean $27.92 \pm 15.38 \mathrm{~mm}$ ) and the weight of males between 2.60 and $115.30 \mathrm{~g}$ (mean $34.30 \pm 24.38 \mathrm{~g}$ ). Statistically significant differences in size and weight $(p<0.05)$ between sexes were found (Figure 2, Table 1); females were smaller than males.

Table 1. Descriptive statistics of total length $(\mathrm{mm})$ and total weight $(\mathrm{g})$ of females $(\mathrm{F})$ and males $(\mathrm{M})$ of M. binghami.

\begin{tabular}{|c|c|c|c|c|c|c|c|c|c|c|c|}
\hline & \multicolumn{6}{|c|}{ Total length (mm) } & \multicolumn{5}{|c|}{ Total weight (g) } \\
\hline Sex & $\mathrm{N}$ & Min. & Max. & Mean & $\begin{array}{l}\text { Standard } \\
\text { deviation }\end{array}$ & $\mathrm{p}$-value & Min. & Max. & Mean & $\begin{array}{l}\text { Standard } \\
\text { deviation }\end{array}$ & p-value \\
\hline $\mathrm{F}$ & 379 & 53.65 & 178.00 & 118.94 & 24.73 & & 1.70 & 79.70 & 27.92 & 15.38 & \\
\hline M & 330 & 60.17 & 191.00 & 123.93 & 29.52 & 0.04 & 2.60 & 115.30 & 34.30 & 24.38 & 0.02 \\
\hline
\end{tabular}



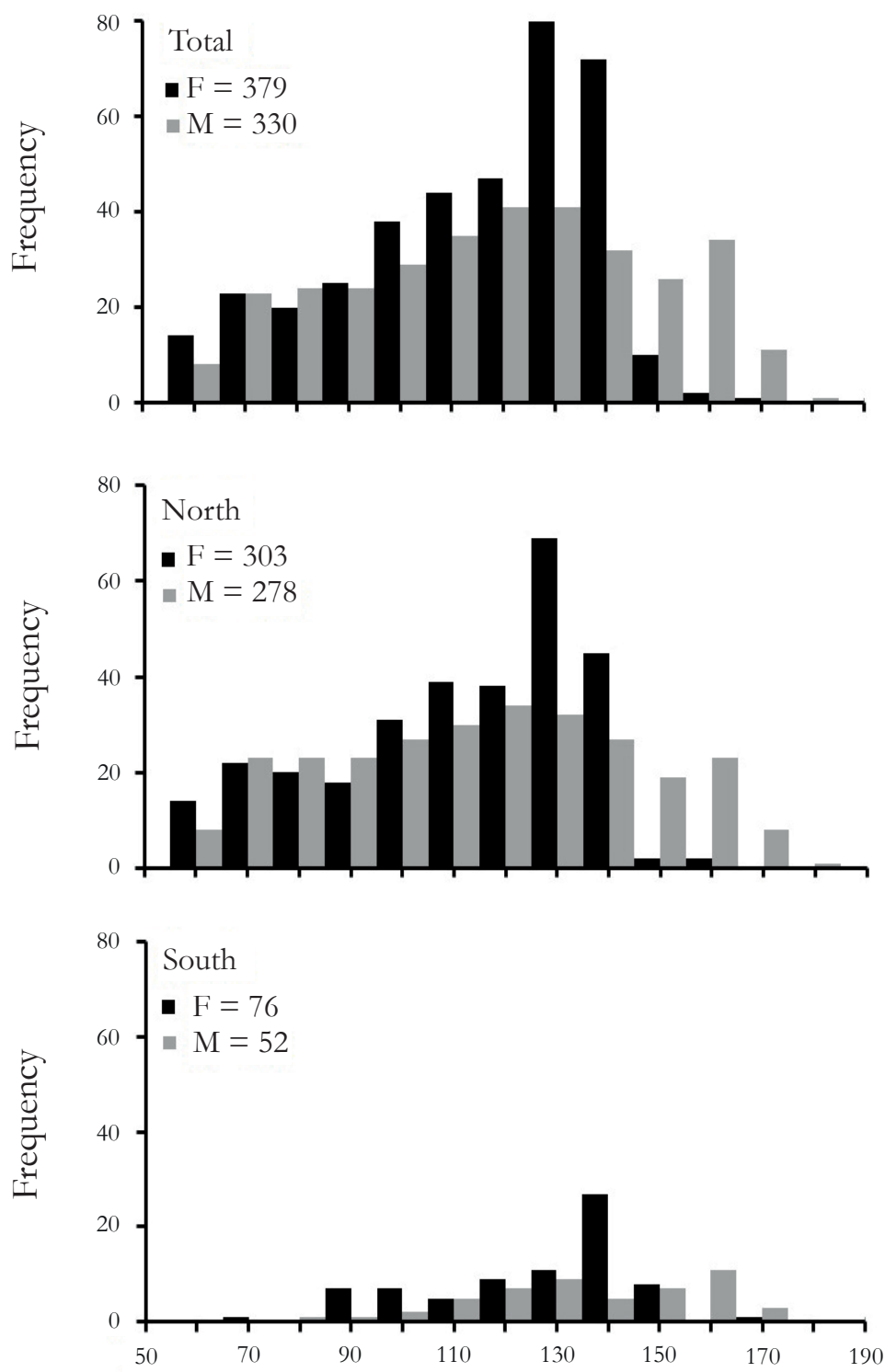

Total Length (mm)

Fig. 2. Total length frequency distributions of $M$. binghami $(\mathrm{mm})$ by sex for total area, north area and south area.

The sex ratio showed significant differences $(\mathrm{p}<0.001)$ between the total number of females and males and per size class when compared with a $50 \%$ of sexual ratio. However, there was no significant difference $(p=0.067)$ between the number of females and males in the size range of 70 to $140 \mathrm{~mm}$ of total length. Females showed a larger proportion in sizes smaller than $65 \mathrm{~mm}$ of total length $(\mathrm{p}<0.001)$. Then, the sex ratio decreased favouring males in sizes ranging from 145 and $190 \mathrm{~mm}$ TL $(p<0.001)$ (Figure 3a). The GAM nonlinear fitting was significant $(p=0.000)$ showing a deviance explained of $88.7 \%$ and the relation between sex ratio and total length $\left(r^{2}=0.839\right)$ shows that this species sex ratio decreases according to total length in the Colombian Caribbean (Figure 3b). 

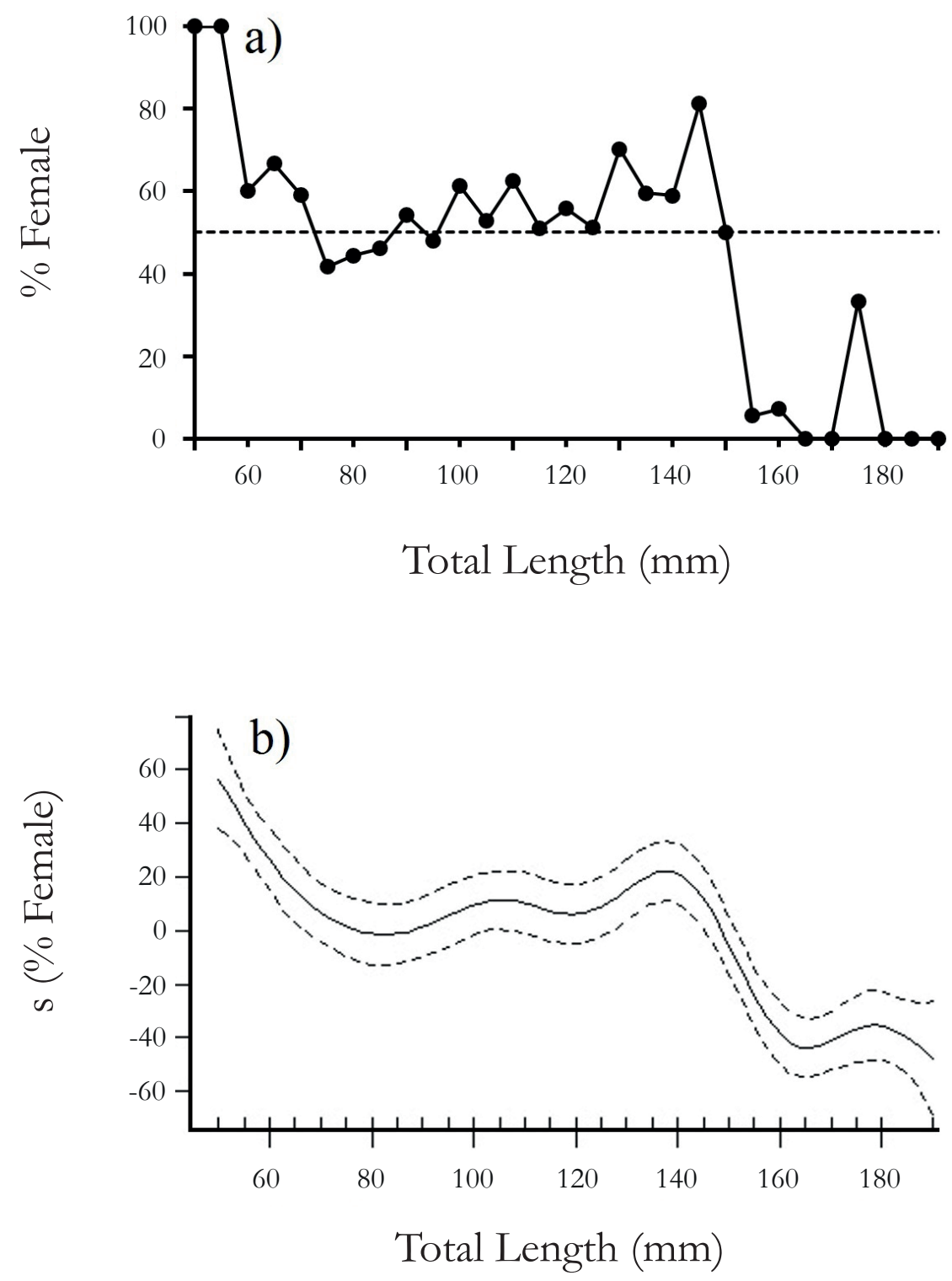

Fig. 3. a) Sex ratio of Caribbean lobster (M. binghami) in the Colombian Caribbean, b) relation between sex ratio and total length obtained by GAM models with spline smoother, continuous line: fitted values, dotted line: confidence intervals.

The size at sexual maturity ( $\mathrm{TL}_{50} \%$ ) of females was $104.56 \mathrm{~mm}$ of TL (31.3\% immature and 68.6\% mature) (Figure 4). The parameters of the logistic model were $\mathrm{a}=13.613$ and $\mathrm{b}=-0.130, \mathrm{r}^{2}=0.99$. Estimates of the break points or beginning of morphometric maturity were performed for all the relationships. However, only the values shown in Table 2 correspond to those estimates that showed significant differences between the slopes (Test Davies, $\mathrm{p}<0.05$ ) and values where the break point analysis showed consistency at the moment of varying the range of the initial value in the algorithm "segment". The slopes of juveniles (first segment) were always 
Table 2. Results of the break point estimated by segmented regression for each morphometric relationship in males and females of $M$. binghami. The intercept and slope are presented for each segment. J: juveniles and A: adults.

\begin{tabular}{|c|c|c|c|c|c|c|c|}
\hline Sex & $\mathrm{n}$ & Relationship & Break point & Stage & Intercept & Slopes & $\begin{array}{c}\text { Davies' test } \\
\text { p-value }\end{array}$ \\
\hline \multirow{14}{*}{ Female } & \multirow{14}{*}{199} & \multirow{2}{*}{ HL vs TL } & \multirow{2}{*}{105.87} & $\mathrm{~J}$ & 2.626 & 0.473 & \multirow{2}{*}{0.000} \\
\hline & & & & A & 8.744 & 0.415 & \\
\hline & & \multirow{2}{*}{ FSH vs TL } & \multirow{2}{*}{106.03} & $\mathrm{~J}$ & -2.342 & 0.144 & \multirow{2}{*}{0.037} \\
\hline & & & & A & 1.031 & 0.112 & \\
\hline & & \multirow{2}{*}{ SISH vs TL } & \multirow{2}{*}{106.40} & $\mathrm{~J}$ & -0.597 & 0.080 & \multirow{2}{*}{0.000} \\
\hline & & & & A & 0.447 & 0.070 & \\
\hline & & \multirow{2}{*}{ HL vs CL } & \multirow{2}{*}{37.68} & $\mathrm{~J}$ & 3.110 & 1.617 & \multirow{2}{*}{0.002} \\
\hline & & & & A & 20.800 & 1.148 & \\
\hline & & \multirow{2}{*}{ FSH vs CL } & \multirow{2}{*}{33.80} & $\mathrm{~J}$ & -2.337 & 0.498 & \multirow{2}{*}{0.000} \\
\hline & & & & A & 2.576 & 0.353 & \\
\hline & & \multirow{2}{*}{ DCL vs CL } & \multirow{2}{*}{31.47} & $\mathrm{~J}$ & -2.358 & 1.226 & \multirow{2}{*}{0.029} \\
\hline & & & & A & 1.005 & 1.119 & \\
\hline & & \multirow{2}{*}{ SSL vs CL } & \multirow{2}{*}{35.95} & $\mathrm{~J}$ & -0.721 & 0.200 & \multirow{2}{*}{0.002} \\
\hline & & & & A & 1.916 & 0.127 & \\
\hline \multirow{8}{*}{ Male } & \multirow{8}{*}{164} & \multirow{2}{*}{ HSW vs TL } & \multirow{2}{*}{119.22} & $\mathrm{~J}$ & -1.713 & 0.170 & \multirow{2}{*}{0.000} \\
\hline & & & & A & -3.297 & 0.183 & \\
\hline & & \multirow{2}{*}{ SISH vs TL } & \multirow{2}{*}{109.40} & $\mathrm{~J}$ & -1.632 & 0.090 & \multirow{2}{*}{0.011} \\
\hline & & & & A & -0.225 & 0.077 & \\
\hline & & \multirow{2}{*}{ FSW vs CL } & \multirow{2}{*}{44.80} & $\mathrm{~J}$ & -1.704 & 0.569 & \multirow{2}{*}{0.012} \\
\hline & & & & A & 4.770 & 0.424 & \\
\hline & & & & $\mathrm{J}$ & -1.065 & 0.291 & \\
\hline & & SISH vs CL & 43.40 & A & 2.850 & 0.201 & 0.040 \\
\hline
\end{tabular}

higher than adults. However, for the relationship (HSW vs TL) in males, the slope of adults was higher than juveniles. The break points found for HL, FSH, SISH vs TL in females were similar. Those performed by the segmented regression with CL as the main measure, ranged from 31.5 to $37.7 \mathrm{~mm}$. For males, the estimated break points with TL ranged from 104.40 to $119.2 \mathrm{~mm}$ and those estimated with CL between 43.4 to 44.8 (Table 2).

Table 3. Descriptive statistics of total length $(\mathrm{mm})$ and total weight $(\mathrm{g})$ of females $(\mathrm{F})$ and males $(\mathrm{M})$ of M. binghami.

\begin{tabular}{|c|c|c|c|c|c|c|c|c|c|}
\hline Sex & $\mathrm{N}$ & $\mathrm{a}$ & a (C.I. 95\%) & $\mathrm{b}$ & b (C.I. 95\%) & $r^{2}$ & $\begin{array}{l}\text { t-test } \\
\text { (b) }\end{array}$ & $\begin{array}{c}\mathrm{F} \\
\text { (ANCOVA) }\end{array}$ & $\begin{array}{l}\text { p- value } \\
\text { (ANCOVA) }\end{array}$ \\
\hline $\mathrm{F}$ & 379 & 5.93E-06 & $\begin{array}{l}4.48 \mathrm{E}-06 \text { to } \\
7.86 \mathrm{E}-06\end{array}$ & 3.185 & $\begin{array}{c}3.126 \text { to } \\
3.245\end{array}$ & 0.967 & 0.000 & 8.988 & 0.002 \\
\hline M & 330 & $3.45 \mathrm{E}-06$ & $\begin{array}{c}2.58 \mathrm{E}-06 \text { to } \\
4.60 \mathrm{E}-06\end{array}$ & 3.301 & $\begin{array}{c}3.241 \text { to } \\
3.361\end{array}$ & 0.972 & 0.000 & & \\
\hline
\end{tabular}




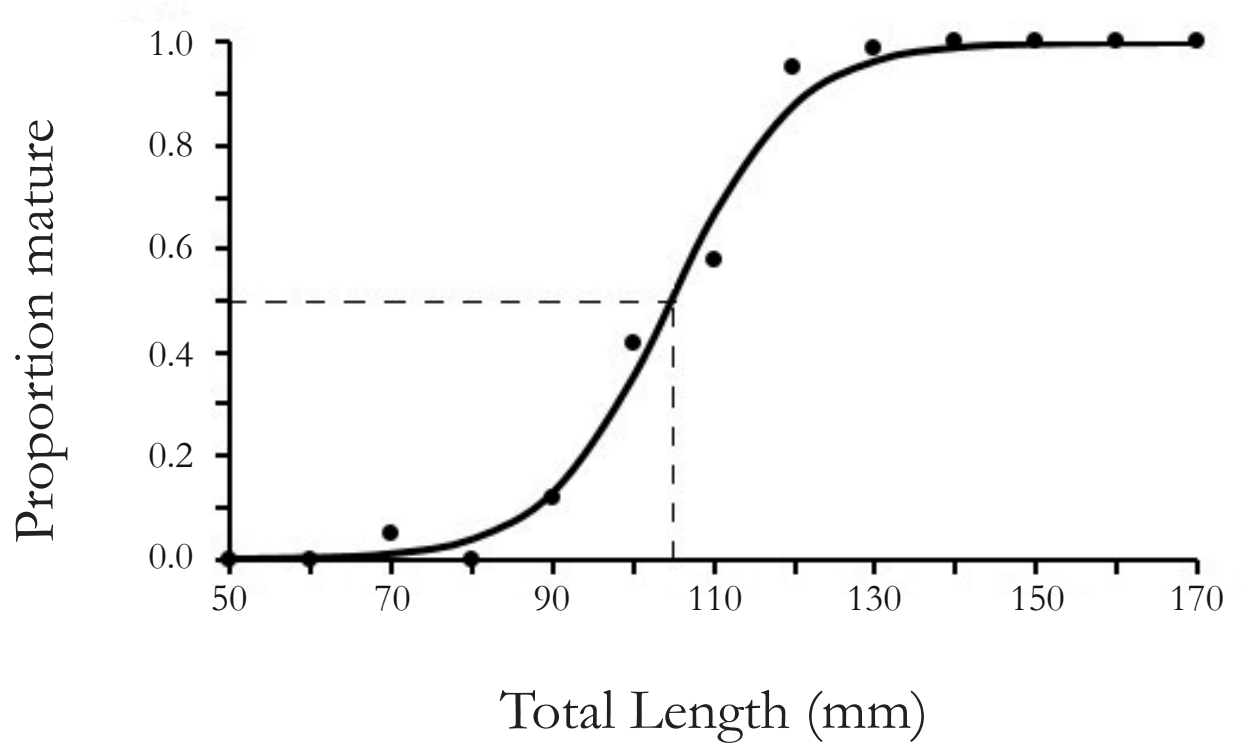

Fig. 4. Size at sexual maturity $\left(\mathrm{LT}_{50} \%\right)$ of females of $M$. binghami in the Colombian Caribbean.

The relationships of total weight with total length for both females and males were significant $(p<0.001)$ and weight variability is explained by about $>90 \%$ for both sexes (Table 3), showing a positive allometric growth $(\mathrm{b}>3)$, where the weight (W) increases to a greater proportion than the size. ANCOVA showed that there are significant differences between the slopes of females and males in the weightlength relationship (Table 3; Figure 5a). The morphometric relationships between TL vs ASW, HSW, CL, DCL, FSL, FSW, FSH, SSL, SISH, TaL and HL showed high determination coefficients $\left(\mathrm{r}^{2}>0.80\right)$, indicating a high correlation between sizes. The ANCOVA showed that there is no statistically significant difference between the parallelism of the slopes of females and males in all linear relationships (Table 4; Figure 5 b-1).

\section{Discussion}

Deep-sea lobsters have a high commercial value in international markets, and there are many fisheries targeting these crustaceans (Holthuis 1991, Bell et al. 2013). Our results show that the sizes of $M$. binghami are similar to those reported for other congeners such as M. mozambicus, which is captured in East Africa by the industrial fishery with a cephalothorax length of $45 \mathrm{~mm}$ (Robey 2013) and is commercialized at a higher price than the spiny lobster (Chan \& Yu 1991). M. japonicas, known as Japanese shrimp, with a total length of $200 \mathrm{~mm}$, has a high economic value, and is a fishery of commercial importance in the Bay of Suruga in Japan where there is a small stock that is subject to high fishing pressure (Okamoto 2008). M. binghami is found in Venezuelan waters with a total length of $206 \mathrm{~mm}$ and is reported as having potential for a new fishery (Gómez et al. 2000, Tavares 2002, Gómez et al. 2005). 
Table 4. Parameters and confidence intervals (95\%) of morphometric relationship in females and males of $M$. binghami. Degrees of freedom for all relationships $=359$.

है
है
0
:
:

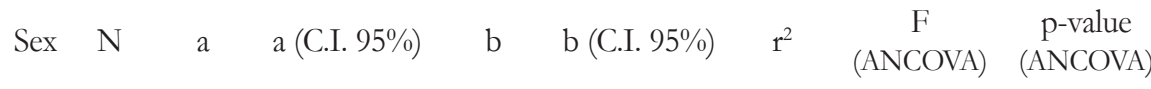

\begin{tabular}{|c|c|c|c|c|c|c|c|c|c|}
\hline \multirow{2}{*}{ 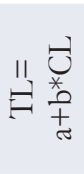 } & $\mathrm{F}$ & 379 & 3.098 & $\begin{array}{c}0.235 \text { to } \\
5.961\end{array}$ & 3.392 & $\begin{array}{c}3.309 \text { to } \\
3.474\end{array}$ & 0.945 & 0.105 & 0.745 \\
\hline & $\mathrm{M}$ & 330 & 2.971 & $\begin{array}{c}0.929 \text { to } \\
5.014\end{array}$ & 3.356 & $\begin{array}{c}3.301 \text { to } \\
3.411\end{array}$ & 0.977 & & \\
\hline \multirow{2}{*}{ 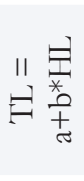 } & $\mathrm{F}$ & 199 & -6.131 & $\begin{array}{c}-9.325 \text { to } \\
-2.936\end{array}$ & 2.161 & $\begin{array}{c}2.107 \text { to } \\
2.213\end{array}$ & 0.971 & 0.717 & 0.397 \\
\hline & M & 164 & -4.894 & $\begin{array}{l}-8.401 \text { to } \\
-1.386\end{array}$ & 2.124 & $\begin{array}{c}2.069 \text { to } \\
2.178\end{array}$ & 0.973 & & \\
\hline \multirow{2}{*}{ 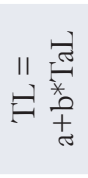 } & $\mathrm{F}$ & 199 & 8.912 & $\begin{array}{c}5.400 \text { to } \\
12.424\end{array}$ & 1.740 & $\begin{array}{c}1.688 \text { to } \\
1.793\end{array}$ & 0.955 & 0.561 & 0.454 \\
\hline & $\mathrm{M}$ & 164 & 9.502 & $\begin{array}{c}6.636 \text { to } \\
12.369\end{array}$ & 1.737 & $\begin{array}{c}1.696 \text { to } \\
1.778\end{array}$ & 0.977 & & \\
\hline \multirow{2}{*}{ 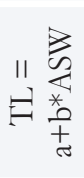 } & $\mathrm{F}$ & 199 & 7.326 & $\begin{array}{c}3.078 \text { to } \\
11.574\end{array}$ & 6.051 & $\begin{array}{c}5.833 \text { to } \\
6.270\end{array}$ & 0.938 & 0.047 & 0.827 \\
\hline & $\mathrm{M}$ & 164 & 6.835 & $\begin{array}{c}2.941 \text { to } \\
10.728\end{array}$ & 6.099 & $\begin{array}{c}5.909 \text { to } \\
6.289\end{array}$ & 0.961 & & \\
\hline \multirow{2}{*}{ 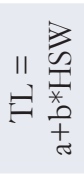 } & $\mathrm{F}$ & 199 & 19.979 & $\begin{array}{c}15.043 \text { to } \\
24.915\end{array}$ & 5.333 & $\begin{array}{c}5.083 \text { to } \\
5.583\end{array}$ & 0.899 & 0.073 & 0.786 \\
\hline & M & 164 & 22.37 & $\begin{array}{c}17.599 \text { to } \\
27.142\end{array}$ & 5.211 & $\begin{array}{c}4.984 \text { to } \\
5.437\end{array}$ & 0.927 & & \\
\hline \multirow{2}{*}{ 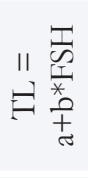 } & $\mathrm{F}$ & 199 & 14.203 & $\begin{array}{c}9.349 \text { to } \\
19.058\end{array}$ & 7.392 & $\begin{array}{c}7.068 \text { to } \\
7.715\end{array}$ & 0.911 & 2.954 & 0.086 \\
\hline & M & 164 & 20.426 & $\begin{array}{c}15.079 \text { to } \\
25.773\end{array}$ & 6.700 & $\begin{array}{c}6.378 \text { to } \\
7.021\end{array}$ & 0.912 & & \\
\hline \multirow{2}{*}{ 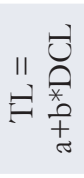 } & $\mathrm{F}$ & 199 & 5.465 & $\begin{array}{c}1.827 \text { to } \\
9.102\end{array}$ & 2.916 & $\begin{array}{c}2.827 \text { to } \\
3.005\end{array}$ & 0.955 & 0.703 & 0.402 \\
\hline & M & 164 & 7.027 & $\begin{array}{c}3.946 \text { to } \\
10.108\end{array}$ & 2.830 & $\begin{array}{c}2.760 \text { to } \\
2.900\end{array}$ & 0.975 & & \\
\hline \multirow{2}{*}{ 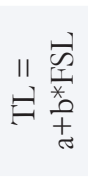 } & $\mathrm{F}$ & 199 & 13.637 & $\begin{array}{c}5.956 \text { to } \\
21.317\end{array}$ & 46.511 & $\begin{array}{c}43.299 \text { to } \\
49.723\end{array}$ & 0.805 & 0.032 & 0.857 \\
\hline & M & 164 & 8.578 & $\begin{array}{c}-0.217 \text { to } \\
17,374\end{array}$ & 48,035 & $\begin{array}{c}44,592 \text { to } \\
51,478\end{array}$ & 0,824 & & \\
\hline \multirow{2}{*}{ 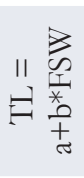 } & $\mathrm{F}$ & 199 & 9.386 & $\begin{array}{c}5.940 \text { to } \\
12.832\end{array}$ & 6.167 & $\begin{array}{c}5.983 \text { to } \\
6.350\end{array}$ & 0.957 & 1.826 & 0.177 \\
\hline & M & 164 & 12.973 & $\begin{array}{c}9.582 \text { to } \\
16.364\end{array}$ & 5.980 & $\begin{array}{c}5.810 \text { to } \\
6.151\end{array}$ & 0.967 & & \\
\hline \multirow{2}{*}{ 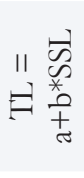 } & $\mathrm{F}$ & 199 & 15.242 & $\begin{array}{l}9.197 \text { to } \\
21.287\end{array}$ & 17.430 & $\begin{array}{c}16.471 \text { to } \\
18.390\end{array}$ & 0.905 & 0.829 & 0.363 \\
\hline & $\mathrm{M}$ & 164 & 10.099 & $\begin{array}{c}4.784 \text { to } \\
15.414\end{array}$ & 18.347 & $\begin{array}{c}17.545 \text { to } \\
19.149\end{array}$ & 0.926 & & \\
\hline \multirow{2}{*}{ 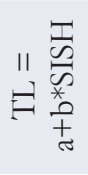 } & $\mathrm{F}$ & 199 & 24.030 & $\begin{array}{c}17.114 \text { to } \\
30.947\end{array}$ & 11.058 & $\begin{array}{c}10.301 \text { to } \\
11.815\end{array}$ & 0.808 & 0.106 & 0.744 \\
\hline & M & 164 & 22.884 & $\begin{array}{c}16.786 \text { to } \\
28.982\end{array}$ & 11.031 & $\begin{array}{c}10.414 \text { to } \\
11.648\end{array}$ & 0.884 & & \\
\hline
\end{tabular}



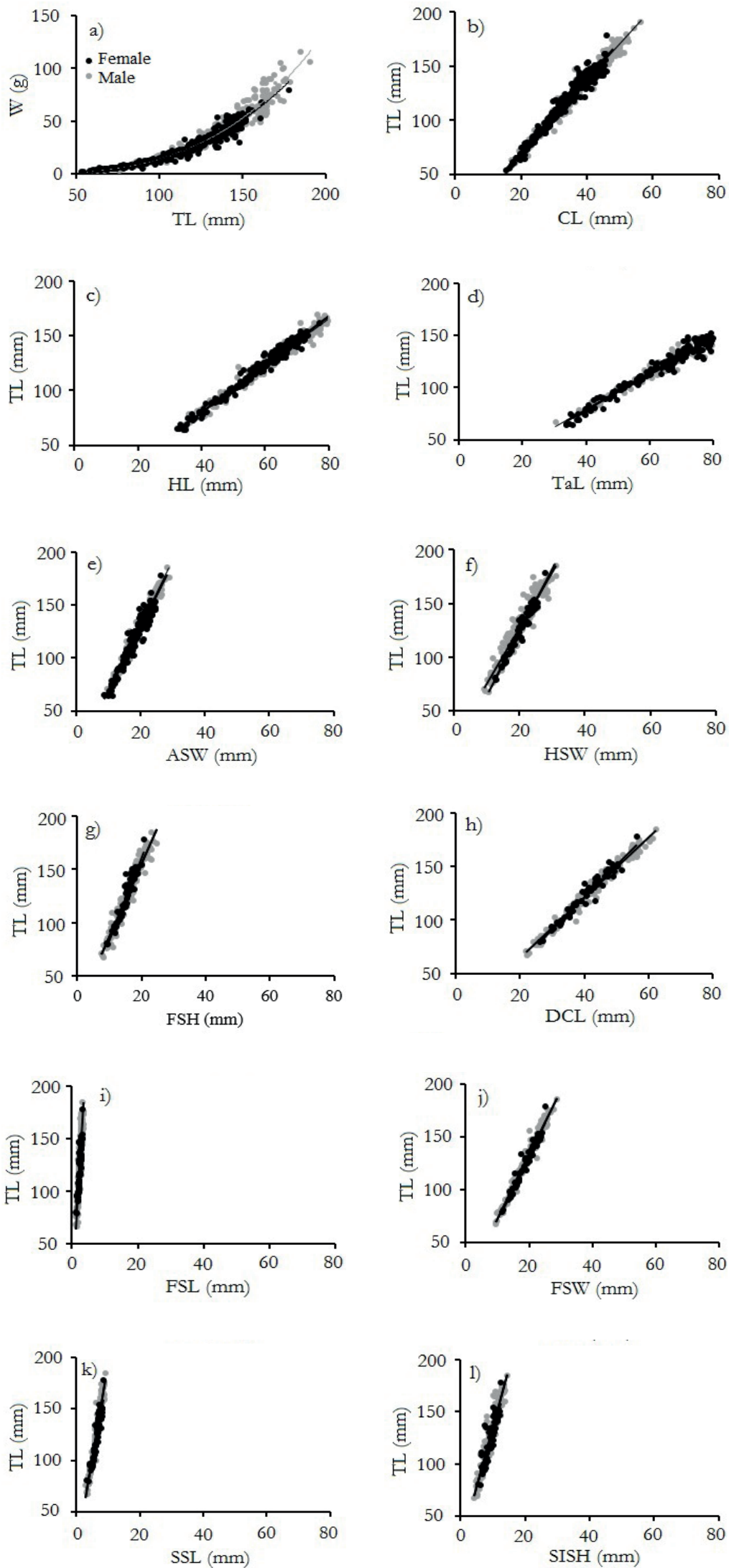

Fig. 5. Morphometric relationships in females and males of the Caribbean lobster (M. binghami). 
In the present study, females of $M$. binghami were smaller than males, similarly to that reported for M. rubellus (Moreira 1903) which shows sizes ranging from 71.3 to 177.7 $\mathrm{mm}$ of TL in the state of São Paulo, Brazil (Severino-Rodrigues et al. 2007, SeverinoRodrigues et al. 2016). For more than two decades M. rubellus has been captured in the landings of pink shrimp (Farfantepenaeus paulensis and F. brasiliensis) in Brazil with sizes ranging from 65 to $186 \mathrm{~mm}$ TL (Severino-Rodrigues 1997, 2016).

Some causes that have been considered in the changes of sex ratio with the size have been the differential mortality, the greater activity of one sex in the reproductive period, the food restriction and the use of different habitats by the two sexes (Company \& Sarda 1997, Koeller et al. 2000, Charnov \& Hannah 2002, Chiba et al. 2006, Ayza 2010, Ayza et al. 2011, Grabowsky et al. 2014). The reason of the change in sex ratio with size may respond to sexual differences in growth, mortality, or migration (Siegel et al.2008). In fact, differences in natural mortality between sexes are a factor that contributes potentially to the unequal sex ratio (Wenner 1972). In this sense, if the rates of growth and mortality of males and females were the same, the sex ratio should remain constant; on the contrary, for increases and reductions in certain size classes, there must be differences in growth rates between females and males. Therefore, the pattern of sex ratio is a result of the mixed effects of differences in growth rates between males and females, mortality rates and age composition (Siegel et al. 2008). The size at sexual maturity is used as a parameter to establish minimum sizes of catches. Therefore, biological research is required to know the reproductive cycle and the factors that affect the success of spawning, which are necessary for the management of fisheries. In Brazil, the size at sexual maturity of females of M. rubellus was $82.5 \mathrm{~mm}$ in total length (Severino-Rodrigues et al. 2016), which is lower than that reported for M. binghami (104.56 $\mathrm{mm}$ in total length) in the Colombian Caribbean. Queirós et al. (2013) consider that total length and cephalothorax length are good predictors for estimating the break point. The size at the beginning of maturity in females estimated from the morphometric data was slightly higher than that estimated with the logistic function. Records of ovigerous females may be underestimated due to the burying behaviour during rest when light increases (Paramo \& Saint-Paul, 2012). In the present study, the first abdominal segment height (FSH) in females had a very close relation with the size at sexual maturity estimated with the logistic function (TL $\mathrm{TL}_{50}=104.56 \mathrm{~mm}$ and $\mathrm{FSH}$ vs TL $=106.031 \mathrm{~mm}$ TL). In the same way, the size at the beginning of maturity estimated by morphometry, taking CL as the primary variable, resulted in a break point (FSH vs CL $=33.797 \mathrm{~mm} \mathrm{CL}$ ) similar to the one reported by Paramo \& SaintPaul (2012) (30.05 mm CL); this finding indicates that FSH is related to size at the beginning of sexual maturity. Therefore, the size of the abdomen is a good indicator of the beginning of morphological sexual maturity since it has a relation with the incubation of eggs.

Females and males showed a positive allometric growth rate similar to that found for this species in Venezuelan waters (Gómez et al. 2005). As a consequence, the Caribbean lobster reveals changes associated with the intrinsic growth rate, obtaining a greater gain in biomass in relation to size (Serrano-Guzmán 2003). Morphometric relationships, besides providing information on growth variation, may also help to predict size at the beginning of maturity and spawning period taking into account changes in the shape and size of the abdomen and pleopods during egg maturation 
(Josileen 2011, Severino-Rodrigues et al.2016). Therefore, further research is necessary on whether morphometric indices are affected or not affected by the particular stage of maturity of the female (Queiros et al. 2013). Paramo \& Saint-Paul. (2012) provided evidence of diel patterns for $M$. binghami that revealed a nocturnal behaviour most likely for feeding and a burying behaviour during daylight, as the largest catches were taken during nocturnal trawls. Consequently, more research is required on seasonal patterns in emergence and sex ratios of $M$. binghami in the Colombian Caribbean. Knowledge of the dimensions of different parts of the body may be useful for studies on the life history of $M$. binghami. The morphometric relationships presented in this work can be very useful for population studies of the same species in different geographic locations. The size structure, size at sexual maturity, growth type and morphometric relationships are important parameters of the life history, as well as of great utility for the management of a new deep-sea fishery in the Colombian Caribbean. This kind of information is very useful for the organizations in charge of establishing fishing management strategies in populations that are still considered unexploited. In this way, management strategies such as closures and fishing gear controls can be implemented thus avoiding resource depletion (Marasco et al. 2007).

\section{Conclusions}

According to the results found, $M$. binghami is a potential alternative resource for the Western Atlantic fishery (Cobb \& Phillips 1980); however, prior to the beginning of a new fishery, more biological research is needed to understand the life cycle parameters of the species such as growth, spawning, recruitment, mortality, spawning areas, nursery areas and associated biodiversity. This information will help in the development of appropriate strategies to initiate and sustain a new commercial fishery in the Colombian Caribbean taking into account the protection and conservation of the ecosystem and contributing to food security.

\section{Acknowledgment}

This work is a contribution of the research group Cienciay Tecnologia Pesquera Tropical-CITEPT (Tropical Fisheries Science and Technology) of the Universidad del Magdalena (Colombia). We thank the crew of the fishing vessel 'Tee Claude' and Captain José Guillén, and the members of the research group CITEPT who participated in the survey. This work was financed by COLCIENCIAS (grant number 117-452-21288), Universidad del Magdalena, Universidad del Magdalena/Gobernación del Magdalena (Agreement No. 089) and the Instituto Colombiano de Desarrollo Rural (INCODER) - Subgerencia de Pesca y Acuicultura.

\section{Conflicts of interest}

The authors declare that there are no conflicts of interest.

\section{References}

Ayza O, Tuset V, González J. Estimation of size at onset of sexual maturity and growth parameters in Norway lobster (Nephrops norvegicus) off the Portuguese coast, Fisheries Research, 108: 205 - 208, 2011.

doi: 10.1016/j.fishres.2010.11.015 
Ayza O. Estudio biológico de la cigala Nephrops norvegïicus (Crustacea: Decapoda) en aguas portuguesas. Facultad de biología, Universidad de las Palmas de Gran Canaria. 30 p. 2010. Retrieved from: http://acceda.ulpgc.es/bitstream/10553/5280/4/0627716_00000_0000.pdf

Bell M, Tuck I, Dobby H. Nephrops species. In: Phillips B (ed). Lobsters: Biology, Management, Aquaculture and Fisheries. John Wiley \& Sons. pp 357 - 413, 2013.

Burnham KP, Anderson DR. Model selection and multimodel inference: a practical information-theoretic approach. Springer- Verlag, New York. 488 p. 2002.

Chan T, Yu H. Studies on the Metanephrops japonicus group (Decapoda, Nephropidae), with descriptions of two new species, Crustaceana, 60(1): 18 - 43, 1991.

doi: 10.1163/156854091X00254

Chan T, Ho KC, Li CP, Chu KH. Origin and diversification of the clawed lobster genus Metanephrops (Crustacea: Decapoda: Nephropidae), Molecular Phylogenetics and Evolution, 50: 411 - 422, 2009.

doi: 10.1016/j.ympev.2008.11.020

Charnov EL, Hannah RW. Shrimp adjust their sex ratio to fluctuating age distributions, Evolutionary Ecology Research, 4: 239 - 246, 2002.

Retrieved from: http://hdl.handle.net/1957/38584

Chiba S, Yoshino K, Kanaiwa M, Kawajiri T, Goshima S. Maladaptive sex ratio adjustment by a sex changing shrimp in selective fishing environments, Journal of Animal Ecology, 82: 632 - 641, 2006.

doi: $10.1111 / 1365-2656.12006$

Cobb JS, Phillips BF. The biology and management of lobsters. Physiology and Behavior Vol 1. Ed. Academic press. 463 p. New York. 1980.

Cobb JS, Wang D. Fisheries biology of lobsters and crayfish. In: Provenzano A (ed). The biology of crustacea. Economic aspects: Fisheries and culture. Academic press, INC. Harcourt Brace Jovanovich. pp 168 - 237. 1985.

Company J.B, Sarda F. Reproductive patterns and populations characteristics of five deep water pandalid shrimps in the western Mediterranean along a depth gradient (150 - 1100 m), Marine Ecology Progress Series, 148:49-58, 1997.

doi: $10.3354 /$ meps148049

Davies RB. Hypothesis testing when a nuisance parameter is present only under the alternative, Biometrika, 74: 33 - 43, 1987.

doi: $10.2307 / 2336019$

Gómez G, Guzmán R, Marcano L. Contribución al conocimiento de la Cigala del Caribe, Metanephrops binghami en aguas de Venezuela: aspectos biométricos y fecundidad, Zootecnia Tropical, 18(1): 107 - 118, 2000.

Gómez G, Marcano L, Guzmán R, Ramírez T. Aspectos biométricos y reproductivos de la cigala, Metanephrops binghami, en aguas de Venezuela, Proceedings of the Forty Seventh Annual Gulf and Caribbean Fisheries Institute, 47: 537 - 547, 2005.

Grabowsky R, Morilhas-Simoes S, Castilho A. Population structure, sex ratio and growth of the seabob shrimp Xiphopenaeus kroyeri (Decapoda, Penaeidae) from coastal waters of southern Brazil, ZooKeys, 457: 253 - 269, 2014.

doi: $10.3897 /$ zookeys.457.6682

Haedrich RL, Barnes SM. Changes over time of the size structure in an exploited shelf fish community, Fisheries Research, 31: 229 - 239, 1997.

doi: 10.1016/S0165-7836(97)00023-4 
Hastie TJ, Tibshirani RJ. Generalized additive models. Ed. Chapman and Hall, London. 352 p. 1990.

doi: 10.1002/0471667196.ess0297.pub2

Hilborn R, Walters CJ. Quantitative fisheries stock assessment. Choice, Dynamics and Uncertainty. Chapman and Hall. 604 p. 1992.

doi: 10.1007/BF00042883

Holthuis LB. Marine lobsters of the world. FAO, Fisheries Synopsis, 13(125):1-253, 1991.

Retrieved from: http://www.fao.org/docrep/009/t0411e/t0411e00.htm

Josileen J. Morphometrics and length-weigt relationship in the blue swimming crab Portunus pelagicus (L. 1758) (Decapoda: Brachyura) from the Mandapam coast, India, Crustaceana, 84(14): 1665 - 1681, 2011.

doi: 10.1163/156854011X607060

King M. Fisheries Biology, Assessment and Management. Oxford: Editorial Wiley-Blackwell. Australia, 400 p. 2007.

Koeller P, Mohn R, Etter M. Density dependant sex change in Northern shrimp, Pandalus borealis, on the Scotian Shelf, Journal of Northwest Atlantic Fishery Science, 27: 107 - 118, 2000 doi: $10.2960 / J . v 27 . a 10$

Marasco RJ, Goodman D, Grimes CB, Lawson PW, Punt AE, Quinn II TJ. Ecosystem-based fisheries management: Some practical suggestions, Canadian Journal of Fisheries and Aquatic Sciences, 64: 928 - 939, 2007.

doi: $10.1139 / \mathrm{f} 07-062$

Mente E, Karapanagiotidis IT, Logothetis P, Vafidis D, Malandrakis E, Neofitou N, Exadactylos A, Stratakos A. The reproductive cycle of Norway lobster, Journal of Zoology, 278: 324 - 332, 2009.

doi: 10.1111/j.1469-7998.2009.00579.x

Muggeo VMR. Estimating regression models with unknown break-points, Statistics in Medicine; 22: 3055 - 3071, 2003.

doi: $10.1002 / \operatorname{sim} .1545$

Muggeo VMR. Segmented: an $\mathrm{R}$ package to fit regression models with broken-line relationships, R News, 8: 20 - 25, 2008.

Retrieved from: https://cran.r-project.org/doc/Rnews/Rnews_2008-1.pdf

Okamoto K. Use of Deep Seawater for Rearing Japanese Scampi Lobster (Metanephrops japonica) Broodstock, Reviews in Fisheries Science, 16(1): 391 - 393, 2008.

doi: 10.1080/10641260701678504

Paramo J, Saint-Paul U. Morphological differentiation of southern pink shrimp Farfantepenaeus notialis in Colombian Caribbean Sea, Aquatic Living Resources, 23(1): 95 - 101, 2010. doi: $10.1051 /$ alr $/ 2010004$

Paramo J, Saint-Paul U. Spatial structure of the Caribbean lobster (Metanephrops binghami) in the Colombian Caribbean Sea, Helgoland Marine Research, 66(1): 25 - 31, 2012.

doi: 10.1007/s10152-011-0243-6

Queirós AM, Weetman A, McLay HA, Dobby H. Geographical variation in size at the onset of maturity of male and female Norway lobster Nephrops norvegicus (L., Homarida: Decapoda) in Scottish waters, Fisheries Research, 139: 132 - 144, 2013

doi: 10.1016/j.fishres.2012.11.002 
Robey J. An assessment of abundance trends and biology of langoustines (Metanephrops mozambicus) and pink prawns (Haliporoides triarthrus) from the deep-water trawl fishery off eastern South Africa. (Thesis M.Sc.). Facultad de Ciencias. Universidad de KwaZulu -Natal, Durban, 2013.

Retrieved from: http://hdl.handle.net/10413/9932

Robey J, Fennessy ST, Everett BI, Santos J, Groeneveld JC. Abundance and biology of the langoustine Metanephrops mozambicus (Nephropidae) on deep-water trawl grounds in eastern South Africa, Journal of Crustacean Biology, 33(6): 760 - 771, 2013.

doi: 10.1163/1937240X-00002194

Serrano-Guzmán SJ. Análisis prospectivo de las relaciones morfométricas de Pinna rugosa Sowerby, 1835 (BIVALVIA: PINNIDAE) en Corralero-Alotengo, Oaxaca, México, Ciencia y Mar, 22: 31 - 39, 2003.

Severino-Rodrigues E, Hebling NJ, Graça-Lopes R. Biodiversidade no produto da pesca de arrasto-de-fundo dirigida ao lagostim Metanephrops rubellus (Moreira 1903) desembarcado no litoral do Estado de São Paulo, Brasil, Boletim do Instituto de Pesca, 33(2): 171-182, 2007.

Severino-Rodrigues E, Gomes-Furquim L, da Graça-Lopes R, Ferreira-Alves PM. Crescimento relativo e tamanho na maturidade sexual do lagostim Metanephrops rubellus (Moreira, 1903) desembarcado no litoral do estado de São Paulo, Brasil. Boletim do Instituto de Pesca. 42(2): 431 - 442, 2016.

doi: 10.5007/1678-2305.2016v42n2p431

Severino-Rodrigues E. Biologia e pesca do lagostim Metanephrops rubellus (Moreira, 1903) desembarcado no litoral do Estado de São Paulo, Brasil (Tese de Doutorado): Universidade Estadual Paulista. 181p., 1997.

Shin YJ, Rochet MJ, Jennings S, Field JG, Gislason H. Using size-based indicators to evaluate the ecosystem effects of fishing, ICES Journal of Marine Science, 62: 384 - 396, 2005.

doi: 10.1016/j.icesjms.2005.01.004

Siegel V, Damm U, Neudecker T. Sex-ratio, seasonality and long-term variation in maturation and spawning of the brown shrimp Crangon crangon (L.) in the German Bight (North Sea), Helgoland Marine Research, 62(4): 339 - 349, 2008.

doi: 10.1007/s10152-008-0121-z

Tavares M. Shrimps. In: Carpenter KE (ed) The living marine resources of the western central Atlantic, species identification guide for fisheries purposes. FAO, Rome, pp 251291, 2002.

Tzeng TD, Chiu CS, Yeh SY. Morphometric variation in red-spot prawn (Metapenaeopsis barbata) in different geographic waters off Taiwan, Fisheries Research, 53: 211 - 217, 2001.

doi: 10.1016/S0165-7836(00)00286-1

Tzeng TD, Yeh SY. Multivariate allometric comparisons for kuruma shrimp (Penaeus japonicus) off Taiwan, Fisheries Research, 59: 279 - 288, 2002.

doi: 10.1016/S0165-7836(01)00403-9

Wenner AM. Sex ratio as a function of size in marine Crustacea, The American Naturalist, 106: 321 - 351, 1972.

Williner V, Torres MV, Carvalho DA, König N. Relative growth and morphological sexual maturity size of the freshwater crab Trichodactylus borellianus (Crustacea, Decapoda, Trichodactylidae) in the Middle Paraná River, Argentina, ZooKeys, 457: 159, 2014.

doi: $10.3897 /$ zookeys.457.6821

Zar JH. Biostatistical analysis, (5 ed.). Pearson. 960p, 2009. 


\section{Relaciones morfométricas y talla de madurez sexual de la langosta de aguas profundas del Caribe Metanephrops binghami (Decapoda: Nephropidae) en el Caribe colombiano}

Resumen. Este artículo describe las relaciones morfométricas y la talla de madurez sexual de la langosta de aguas profundas del Caribe. Los datos se obtuvieron en el Caribe colombiano en 4 campañas de pesca de arrastre en noviembre y diciembre de 2009, entre los 200 y $550 \mathrm{~m}$ de profundidad. Se midieron 709 individuos, con tamaños entre 53.65 y $191.00 \mathrm{~mm}$ (TL) (promedio $121.17 \pm 27.13 \mathrm{~mm}$ ). M. binghami presentó crecimiento alométrico positivo. Las langostas de la familia Nephropidae tienen una amplia distribución mundial e importancia económica, y en el Caribe colombiano se han reportado altos niveles de biomasa de Metanephrops binghami. Esta especie podría representar un nuevo recurso para las pesquerías del Atlántico occidental; sin embargo, antes de desarrollar una nueva explotación pesquera, es necesario entender el ciclo de vida de esta especie en aspectos tales como crecimiento, reproducción, reclutamiento, mortalidad y áreas de crianza y diversidad asociada.

Palabras clave: Metanephrops binghami; relaciones morfométricas; langosta de aguas profundas del Caribe.

\section{Relaçóes morfométricas e tamanho na maturidade sexual de lagostas de profundidade do Caribe Metanephrops binghami (Decapoda: Nephropidae) no Caribe Colombiano}

Resumo. Lagostas da família Nephropidae tem uma ampla distribuição e importância comercial em todo o mundo. Metanephrops binghami tem sido reportada com elevados níveis de biomassa no Caribe Colombiano. Este artigo descreve as relações morfométricas e tamanho na maturidade sexual de lagostas de profundidade do Caribe. Os dados foram obtidos no Caribe Colombiano em quatro pesquisas de arrasto em novembro e dezembro de 2009, entre 200 e 550 metros de profundidade. Foram medidos 709 indivíduos com tamanhos entre 53,65 e 191,00 mm (TL) (média 121,17 \27,13 $\mathrm{mm})$. M. binghami teve um crescimento alométrico positivo. Esta espécie pode converter-se em uma nova fonte potencial para a pesca Atlântica-ocidental. Entretanto, previamente ao desenvolvimento de uma nova atividade de pesca, mais pesquisas biológicas são necessárias para compreender os parâmetros do ciclo de vida de esta espécie, tais como seu crescimento, desova, recrutamento, mortalidade, áreas de desova e de berçário e biodiversidade associada.

Palavras-chave: Metanephrops binghami; relações morfométricas; lagosta de profundidade do Caribe.

\section{José Cusba}

Is a Fishing Engineer at the University of Magdalena. Currently he is a young researcher. He has worked in areas of fisheries acoustics, classification of seabed using acoustic, fishing technology applied to the minimization of impacts of fishing and Deepwater fisheries. He is currently working on the spatial-temporal distribution of billfish species that are target of marine recreational fishing in relation to oceanographic conditions.

\section{Jorge Paramo}

Is a Fishing Engineer from the University of Magdalena (Colombia), with Master (M.Sc.) in Fisheries at the University of Concepcion (Chile) and a Doctorate (Ph.D.) in Natural Sciences at the University of Bremen/ Center for Tropical Marine Ecology (ZMT) (Germany). Areas of research: Crustacean biology, Deep-sea fisheries, Ecosystem approach to fisheries, Marine protected areas, Recreational fisheries, Stock assessment, Fisheries oceanography, Marine ecology, Fisheries management, Fish school behavior, Fisheries acoustics, Population fish dynamics, Geostatistics. 